\title{
Fungi infection in honeybee hives in regions affected by Brazilian sac brood
}

\author{
[Contaminação fúngica em colmeias de abelhas de regiões afetadas \\ pela cria ensacada brasileira] \\ K.M. Keller ${ }^{1}$, M.V. Deveza ${ }^{2}$, A.S. Koshiyama ${ }^{3}$, W.S. Tassinari ${ }^{2}$, O.M. Barth ${ }^{4}$, \\ R.N. Castro ${ }^{2}$, M.C. Lorenzon ${ }^{2}$ \\ ${ }^{1}$ Escola de Veterinária - Universidade Federal de Minas Gerais - UFMG - Belo Horizonte, MG \\ ${ }^{2}$ Universidade Federal Rural do Rio de Janeiro - UFRRJ - Seropédica, RJ \\ ${ }^{3}$ Pontifícia Universidade Católica do Rio de Janeiro - PUC-Rio - Rio de Janeiro, RJ \\ ${ }^{4}$ Instituto Oswaldo Cruz - Fiocruz - Rio de Janeiro, RJ
}

\begin{abstract}
The Brazilian Sac Brood is a disease that affects apiaries of Africanized bee hives in Brazil, thereby making them susceptible to high losses. This study investigated the pathogenicity of Africanized bee hives by the entomopathogenic fungi in a Brazilian Sac Brood endemic region. The degree of fungal contamination, presence of mycotoxins in beehive elements, and vulnerability of healthy beehives in environments subjected and not subjected to the disease were investigated. From the contaminating fungal load, species that are mycotoxin producers and pathogenic causing mortality in the bees have been isolated. The analysis of bee pollen and bee bread samples did not show the presence of the toxic pollen of Stryphnodendron (Fabaceae), which has been indicated as the causative agent of mortality in pre-pupal stage larvae. However, bee bread showed the highest correlation between substrate and fungal contamination.
\end{abstract}

Keywords: bee health, beekeeping, molds, mycotoxins

\section{RESUMO}

A cria ensacada brasileira é uma doença que afeta apiários de colmeias de abelhas africanizadas no Brasil, tornando-os suscetíveis a perdas elevadas. Este estudo investigou a patogenicidade de fungos entomopatogênicos em colmeias de abelhas africanizadas de uma região endêmica de cria ensacada brasileira. O grau de contaminação fúngica, a presença de micotoxinas em elementos colmeia e a vulnerabilidade das colmeias saudáveis em ambientes sujeitos e não sujeitos à doença foram investigados. A partir da carga fúngica contaminante, espécies produtoras de micotoxinas e patogênicas, que provocam a mortalidade de abelhas, foram isoladas. A análise do pólen e do pão de abelha não demonstrou a presença do pólen tóxico de Stryphnodendron (Fabaceae), que tem sido apontado como agente causador da mortalidade de larvas em fase de pré-pupa. No entanto, o pão de abelha foi o substrato mais correlacionado com a contaminação fúngica.

Palavras-chave: sanidade apícola, apicultura, fungos, micotoxinas

\section{INTRODUCTION}

Honeybees are vulnerable throughout their life to a continuous onslaught of various saprophytic microorganisms, pathogens, and parasites. In response to infections and lesions, the bees have developed several immunity processes to prevent invaders from reaching the hemocele (Dunn,

Recebido em 30 de junho de 2013

Aceito em 22 de abril de 2014

*Autor para correspondência (corresponding author)

E-mail: kelly.medvet@gmail.com
1986). Additionally, unhealthy ecosystems may facilitate the development of microorganisms and parasites, as well as promote their spread worldwide.

Brazilian Sac Brood (BSB) is an important threat to honey bee health in Brazil, occurring mainly in southeast Brazil, thereby incurring huge losses in the bee populations (Carvalho and Message, 
2004). This disease is characterized by brood that fails to pupate and subsequently dies (Castagnino et al., 2011). The rapid symptomatology hinders the identification of the principal symptoms, the high larval mortality leads the invasion of the opportunistic microbes, and the swarms absconding from the hive. According to Message et al. (1995), BSB symptoms are similar to Sac Brood Virus (SBV) and until the year 2012, a previous investigation of numerous samples of larvae with sacbrood-like symptoms collected from various parts of Brazil found no evidence of this virus, based on viral particle morphology and serological methods. Recently, SBV had the first detection in Brazil distinct from the regions which have the occurrence of BSB (Freiberg et $a l .$, 2012). Investigations in the Brazilian apiaries show that the cause of BSB is the consumption of tannin by the bees, which is a toxic substance that enters the beehive via the pollen loads from Stryphnodendron (Fabaceae) flowers (Cintra, 2002; Message, 2002). However, studies have shown regions with cases of BSB where the consumption of toxic pollen has not been verified in the beehive (Pacheco, 2009), suggesting that this disease may have another causative agent.

In hot climates it is possible that the fungi affect the bee larvae despite showing no visible symptoms. Fungi are disease vectors that are commonly associated with beehives, and under certain abiotic conditions some fungal species produce mycotoxins. Aspergillus flavus, Aspergillus niger aggregates, and Aspergillus fumigatus are entomopathogenic species of bees that can cause the reduction of immunity in the insects leaving them prone to infection by other disease vectors and causative agents (Gliński and Buczek, 2003). Certain factors may predispose to fungal infections, such as stress, pollution, and pesticide poisoning (Soutwick, 1994; Gliński and Jarosz, 2001).

Considering the suspicion of BSB fungal contamination in Africanized bee hives, this study aimed to investigate the degree of fungal contamination within elements of beehives in regions with and without BSB and correlate the fungi with the vulnerability of the beehives to the disease.

\section{MATERIALS AND METHODS}

This experiment was conducted in two different regions called $\mathrm{A}$ and $\mathrm{B}$. The study regions belong to different counties and are located in the southern part of the state of Rio de Janeiro. They have mountainous formations with wellfragmented Atlantic forest vegetation, the climate and floral species are similar. The majority of rural communities are farming families, livestock and tourism are the main sources of livelihood while beekeeping is not, despite the good conditions to raise honeybees. The average annual honey yield in the regions is close to $20 \mathrm{~kg}$ per hive.

Region $\mathrm{A}$ is free from $\mathrm{BSB}$ and region $\mathrm{B}$ is a BSB-endemic region. From region B, one apiary was chosen to set up this study; it has 10 hives and its records show high loss of hives, affected by BSB, during August and September (the season of nectar flux). From region A, another apiary was chosen, 5 from 18 hives were randomly selected to move to region $\mathrm{B}$. The two regions are $60 \mathrm{~km}$ apart. Both the regions showed abundant plant life for the production of honey from the flowers of Vernonia and Eucalyptus blossoms before the spread of BSB.

Samples collected from beehives in both the regions included honeycombs with offspring nest, food (honey and bee bread), and adult bees. Next, the beehives were transferred from region A to B; samples were collected weekly until the first typical symptom of BSB infection was observed. From the collected samples, honeycomb pieces of approximately $5-\mathrm{cm}$ diameter containing bee bread, honey, and last instar larvae (prepupal stage) were collected; ten adult bees were also collected from the honeycombs. The samples were placed in sterile flasks and refrigerated immediately. All the sample collection and analyses procedures followed the principles of good hygiene practices (Senai, 2009).

In the laboratory, the refrigerated samples were subjected to melissopalynological analysis, without acetolysis (Louveaux et al., 1970; Barth and Luz, 1998; Luz et al., 2007) and measurements of water activity (Aw). The total microbiota count and isolation was performed using Petri dishes by the serial dilution method (Pitt and Hocking, 2009). The inoculation was 
performed in triplicates, and the culture media used were dichloran rose bengal chloramphenicol agar (DRBC), dichloran glycerol at $18 \%$ agar (DG18), and Nash-Snyder agar (NSA) (Nelson et al., 1983). The identification was based on the genus and species of all the colonies according to Samson et al. (2000), Klich (2002), Pitt (1988) and Nelson et al. (1983). To characterize the toxigenic profile, strains of Flavi and Nigri sections of Aspergillus were analyzed according to Geisen (1996) and Bragulat et al. (2001), respectively.

The statistical modeling was conducted by experimental design by using Latin squares containing data from the three treatments for the various culture mediums used for identifying the fungi (DRBC, DG18, NSA), two blocks for the period (pre-transfer and post-transfer), and four blocks for the samples analyzed (honey, bee bread, larvae, and adult bees). The analysis results of all these variables were provided as colony forming units $\left(\mathrm{cfu} \cdot \mathrm{g}^{-1}\right)$. Variance analysis was applied to the model defined using the following formula:

$$
\begin{gathered}
Y_{i j}(k)=\mu+\pi_{i}+\beta_{i}+\tau_{(k)}+\varepsilon_{i j} \\
i=1,2 ; j=1,2,3,4 ; k=1,2,3
\end{gathered}
$$

where $\mathrm{Y}_{i j}(k)$ is the response variable (fungal enumeration), explained by the overall mean $\mu$, effect of the $i$-th block $\pi_{i}$ (period), results presented in the $j$-th block $\beta_{j}$ (four substrates), and based on the $k$-th treatment $\tau_{(k)}$ (culture media). $\varepsilon_{i j}$ represents the residue. To assess the significant differences in the means of the analyzed treatments, the Tukey test was used at $5 \%$ significance level (Hinkelmann and Kempthorne, 2008).

\section{RESULTS AND DISCUSSION}

After 15 days of the arrival of the hives from region $A$ to region $B$, the fungi infection increased in the majority of the hives (region $\mathrm{A}$ ). The main symptom is the fail of the pupation and the acute spread in the apiary of region B. This region had already been diagnosed with BSB.

During the time of this study, the analysis of bee pollen and bee bread samples did not show the presence of the toxic pollen of Stryphnodendron (Fabaceae) (Table 1), which has been indicated as the causative agent of mortality in pre-pupal stage larvae. Moreover, study results, as well as assay results of samples from other counties of the state of Rio de Janeiro where BSB is prevalent, also did not show the presence of this toxic pollen. Nonetheless, in other states in the Southeast and Central regions of Brazil, the presence of tannin in the pollen of Stryphnodendron is considered the causative agent of BSB.

Table 1. Types of pollen and impurities in samples of bee bread $(n=18)$ collected from colonies of Africanized bees in regions with and without BSB in the state of Rio de Janeiro, Brazil

\begin{tabular}{cl}
$\begin{array}{c}\text { Total pollen grains from } \\
\text { each sample }\end{array}$ & Classification \\
\hline 566 & Dominance of Eucalyptus with minor levels of Asteraceae \\
522 & Dominance of Eucalyptus with minor levels of Eupatorium \\
539 & Dominance of Eucalyptus with minor levels of Eupatorium \\
509 & Purely Eucalyptus \\
556 & Purely Eucalyptus \\
570 & Dominance of Alchornea with minor levels of Eucalyptus \\
758 & Purely Eucalyptus \\
585 & Purely Alchornea \\
526 & Bifloral, Eupatorium and Vernonia \\
564 & Dominance of Eucalyptus with minor levels of Cecropia \\
528 & Dominance of Eucalyptus with minor levels of Vernonia \\
576 & Dominance of Eucalyptus with minor levels of Rubiaceae and Vernonia \\
551 & Purely Eucalyptus \\
510 & Purely Eucalyptus \\
537 & Dominance of Vernonia with minor levels of Eucalyptus \\
521 & Dominance of Eucalyptus with minor levels of Vernonia \\
544 & Dominance of Eucalyptus with minor levels of Arecaceae \\
543 & Dominance of Eucalyptus with minor levels of Vernonia \\
\hline
\end{tabular}


Regarding fungal contamination, the temporal analysis of the level of contamination in the beehives, pre- and post-transfer, showed a high increase in the level of beehive contamination in all culture media (Table 2). The magnitude of the fungal contamination was perceived (Table 3) soon after the transfer to region $\mathrm{B}$. These results indicate that the infection has its origin in certain unhealthy environments, such as the test location (region B), which must be prone to fungal contamination agents and has conditions that promote and favor the emergence of these microbial agents.

Table 2. Mean fungal load $\left(\mathrm{cfu} \cdot \mathrm{g}^{-1}\right)$ and variance coefficient $(\%)$ of honeybee substrates, pre-transfer (region A) and post-transfer (region B)

\begin{tabular}{|c|c|c|c|c|c|c|c|c|}
\hline \multirow{2}{*}{$\begin{array}{l}\text { Variables } \\
\text { Period }\end{array}$} & \multicolumn{2}{|c|}{$\begin{array}{c}\text { Honey } \\
\mathrm{cfu} \mathrm{g}^{-1} \text { and }\left(\mathrm{CV}^{\mathrm{c}}\right)\end{array}$} & \multicolumn{2}{|c|}{$\begin{array}{c}\text { Bee bread } \\
\text { cfu } \mathrm{g}^{-1} \text { and }(\mathrm{CV})\end{array}$} & \multicolumn{2}{|c|}{$\begin{array}{c}\text { Bee larvae } \\
\mathrm{cfu} \mathrm{g}^{-1} \text { and }(\mathrm{CV})\end{array}$} & \multicolumn{2}{|c|}{$\begin{array}{c}\text { Bee adults } \\
\mathrm{cfu} \mathrm{g}^{-1} \text { and }(\mathrm{CV})\end{array}$} \\
\hline & $\mathrm{PeT}^{\mathrm{a}}$ & $\mathrm{PoT}^{\mathrm{b}}$ & $\mathrm{PeT}^{\mathrm{a}}$ & $\mathrm{PoT}^{\mathrm{b}}$ & $\mathrm{PeT}^{\mathrm{a}}$ & $\mathrm{PoT}^{\mathrm{b}}$ & $\mathrm{PeT}^{\mathrm{a}}$ & $\mathrm{PoT}^{\mathrm{b}}$ \\
\hline $\mathrm{DRBC}^{\mathrm{d}}$ & $\begin{array}{c}2.0 \times 10^{2} \\
(58 \%)\end{array}$ & $\begin{array}{l}6.1 \times 10^{5} \\
(142 \%)\end{array}$ & $\begin{array}{c}2.3 \times 10^{5} \\
(64 \%)\end{array}$ & $\begin{array}{c}5.4 \times 10^{6} \\
(74 \%)\end{array}$ & $\begin{array}{l}2.4 \times 10^{3} \\
(149 \%)\end{array}$ & $\begin{array}{c}4.0 \times 10^{5} \\
(70 \%)\end{array}$ & $\begin{array}{c}7.0 \times 10^{3} \\
(74 \%)\end{array}$ & $\begin{array}{c}6.0 \times 10^{5} \\
(91 \%)\end{array}$ \\
\hline DG1 $8^{\mathrm{e}}$ & $\begin{array}{c}1.3 \times 10^{2} \\
(40 \%)\end{array}$ & $\begin{array}{l}5.3 \times 10^{5} \\
(172 \%)\end{array}$ & $\begin{array}{c}2.2 \times 10^{5} \\
(89 \%)\end{array}$ & $\begin{array}{c}4.4 \times 10^{6} \\
(76 \%)\end{array}$ & $\begin{array}{l}2.7 \times 10^{3} \\
(178 \%)\end{array}$ & $\begin{array}{l}1.4 \times 10^{5} \\
(123 \%)\end{array}$ & $\begin{array}{l}1.2 \times 10^{4} \\
(124 \%)\end{array}$ & $\begin{array}{c}3.3 \times 10^{4} \\
(62 \%)\end{array}$ \\
\hline $\mathrm{NSA}^{\mathrm{e}}$ & $\begin{array}{l}3.3 \times 10^{2} \\
(138 \%)\end{array}$ & $\begin{array}{l}3.4 \times 10^{5} \\
(124 \%)\end{array}$ & $\begin{array}{c}3.4 \times 10^{5} \\
(87 \%)\end{array}$ & $\begin{array}{l}2.6 \times 10^{6} \\
(65 \%)\end{array}$ & $\begin{array}{l}8.9 \times 10^{3} \\
(161 \%)\end{array}$ & $\begin{array}{l}5.5 \times 10^{4} \\
(175 \%)\end{array}$ & $\begin{array}{c}6.0 \times 10^{3} \\
(87 \%)\end{array}$ & $\begin{array}{l}3.5 \times 10^{4} \\
(125 \%)\end{array}$ \\
\hline
\end{tabular}

${ }^{a} \mathrm{PeT}$, pre-transfer; ${ }^{\mathrm{b}} \mathrm{PoT}$, post-transfer, ${ }^{\mathrm{c}}$ coefficient of variance; ${ }^{\mathrm{d}}$ dichloran rose bengal chloramphenicol agar;

${ }^{\mathrm{e}}$ dichloran glycerol at $18 \%$ agar; ${ }^{\mathrm{f}} \mathrm{Nash}-$ Snyder agar

Table 3. Increase in the fungal contamination of honeybee substrates after transfer of the beehive from the region without BSB (A) to the region with BSB (B)

\begin{tabular}{|c|c|c|c|c|}
\hline Culture mediums & Honey & Bee bread & Bee larvae & Bee adults \\
\hline $\mathrm{DRBC}^{\mathrm{a}}$ & $304900 \%$ & $2274 \%$ & $16132 \%$ & $8471 \%$ \\
\hline DG $18^{b}$ & $423900 \%$ & $1891 \%$ & $5157 \%$ & $2596 \%$ \\
\hline $\mathrm{NSA}^{\mathrm{c}}$ & $103054 \%$ & $671 \%$ & $523 \%$ & $480 \%$ \\
\hline
\end{tabular}

${ }^{a}$ dichloran rose bengal chloramphenicol agar; ${ }^{b}$ dichloran glycerol at $18 \%$ agar; ${ }^{\mathrm{c}} \mathrm{Nash}-$ Snyder agar

Among the three culture medias, DRBC showed the highest efficiency, which is expected considering that it is a general culture medium that allows growth in ideal conditions for a wide variety of fungi. Additionally, the variance analysis shows differences in the contamination due to the nature of the substrate $(p$-valor $<0.01)$ (Table 4). The bee bread showed the highest fungal load. Although the other substrates showed high levels of contamination, the differences are not significant $(p$-valor $>0.05)$ (Figure 1). The evidence of infection in the bee bread reinforces the biologically indicative action of this substrate.

When narrowing the analysis results to the substrates in pairs, it can be verified that the bee bread and adult bees are the most infected beehive elements (Figure 1). This could be because pollen is a substrate that is rich in fatty acids and easily contaminated (Hani et al., 2012) thus, favoring the adhesion of propagules from fungi to the hair on the body of adult foraging bees. However, honey was the least exposed substrate in the beehive, because the nectar from the flowers is the least exposed to contamination, and once collected by the bee, it undergoes a major transformation and is concentrated.

Table 4. Variance analysis and Jarque-Bera goodness-of-fit test results.

\begin{tabular}{lll} 
Variables & \multicolumn{2}{l}{ Fungal load $\left(\mathrm{cfu} \cdot \mathrm{g}^{-1}\right)$} \\
& Explanation & $p$ value \\
\hline Culture mediums & $1.19 \%$ & 0.16 \\
Substrate & $33.87 \%$ & $<0.01$ \\
Transfer & $38.49 \%$ & $<0.01$ \\
Residue & $17.63 \%$ & $0.43^{\mathrm{a}}$
\end{tabular}

${ }^{\mathrm{a}} p$ value related to the Jarque-Bera goodness-of-fit test (Jarque and Bera, 1987). 


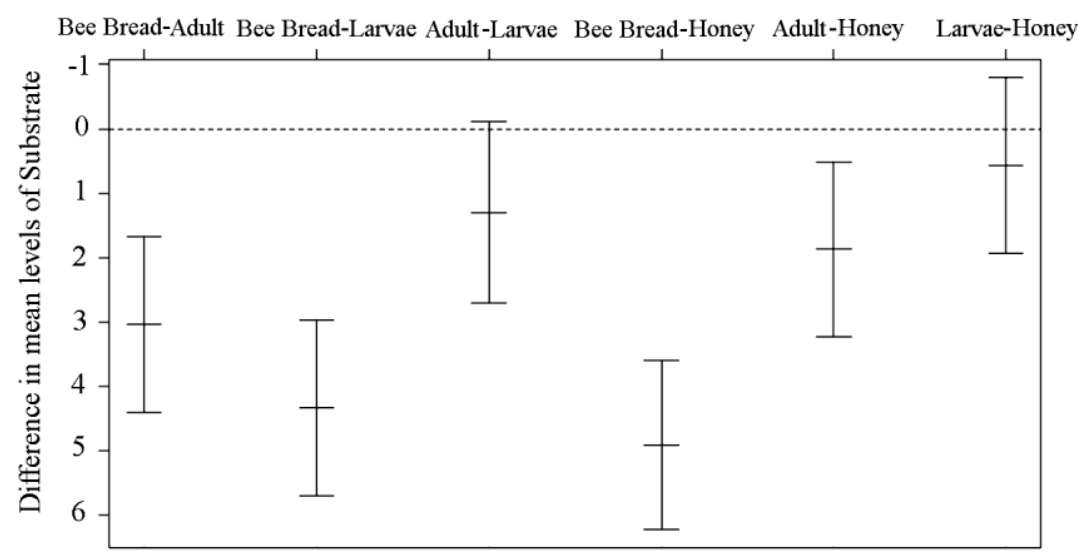

Figure 1. Difference in the means of the analyzed substrates, namely: honey, bee bread, larvae, and adult bees, using the Tukey range test.

Studies have shown that fungal growth in the beehive, especially on the bee bread, occurs under intense water shortage. In this substrate, the Aw was close to 0.64. Moreover, studies have shown that filamentous fungi germinate in various substrates where the Aw varies between 0.65 and 0.90 (Pitt and Hocking, 2009), which is beyond the production of toxic metabolites (mycotoxins) (Rosa et al., 2006). Most microorganisms responsible for the breakdown of food do not develop under low limits of Aw, a situation that favors and selects the presence of xerophilic fungal species, which is in contrast with the bee-bread contamination shown in this study.

Possibly, the fungal strains may have used honey as the ideal medium to obtain the required moisture, since inside a beehive honey is the substrate having a moisture level of more than $25 \%$ at the immature stage. Furthermore, since honey was available abundantly (more than 15 $\mathrm{kg}$ per beehive), it may have supplied enough energy to warrant fungal growth. This fungal infection is considered vertiginous, with the highest infection time (Table 2).

In the microbiota from beehives in region $\mathrm{A}$, Cladosporium spp., which was present in all samples, was isolated. Aspergillus was the second most isolated genus; all the identified species were potential mycotoxin producers: Penicillium citrinum - citrinin; Aspergillus flavus - aflatoxins; and Aspergillus niger aggregates ochratoxin A. Cladosporium was the most frequently observed genus $(75 \%)$ even in bee-bread samples from region B. However, high colonization by a diversified fungal microbiota was observed with the presence of the three main mycotoxin-producing genera, namely Aspergillus, Penicillium, and Fusarium. Thus, the most commonly identified species were potential mycotoxin producing fungi (Table 5).

The rapid onset of contamination (2 weeks) is enough time for the emergence and propagation of opportunistic fungi such as Aspergillus niger aggregates and Aspergillus flavus, which are bee pathogens (Gliński and Buczek, 2003). The presence of different fungal species may create competition between the fungi and the organism, thus, unleashing pathogenicity by mycosis in the beehive (Gliński and Jarosz, 2000).

The release of mycotoxin-producing species of aflatoxins and ochratoxin A, was verified, and strains of Aspergillus flavus, which produced aflatoxin $\mathrm{B}_{1}$, were isolated. According to Hilldrup and Llewellyn (1979), Apis mellifera is the most sensitive to aflatoxin $\mathrm{B}_{1}$; however, identifying its susceptibility to other mycotoxins requires further research. The presence of aflatoxins in the diet of bees may cause high mortality even at concentrations below $5 \mu \mathrm{g} \mathrm{g}^{-1}$. Aflatoxins act directly on the central nervous system, affect the endocrine system, and compromise the internal defense system of bees, while reducing resistance to mycotic infection (Gliński and Buczek, 2003). Hilldrup et al. (1977) verified the production of aflatoxins in low levels in samples of pollen, honeycomb (nest), larvae, and adult bees, except in unprocessed honey. 
Table 5. Fungal load $\left(\mathrm{cfu} \cdot \mathrm{g}^{-1}\right)^{\mathrm{a}}$ in beebread samples (DRBC culture medium), isolated microbiota, and relative density and frequency of fungal species from beehives that sustained fungal infections.

\begin{tabular}{|c|c|c|c|}
\hline Region without BSB (region A) & & Region with BSB (region B) & \\
\hline Fungi-genera and species & & Fungi-genera and species & \\
\hline Frequency & & Frequency & \\
\hline Cladosporium & $100 \%$ & Cladosporium & $75 \%$ \\
\hline Aspergillus & $50 \%$ & Aspergillus & $75 \%$ \\
\hline Trichoderma & $50 \%$ & Fusarium & $50 \%$ \\
\hline Wallemia & $25 \%$ & Penicillium & $50 \%$ \\
\hline & & Paecilomyces & $25 \%$ \\
\hline Relative density & & Relative density & \\
\hline Penicillium citrinum & $100 \%$ & Penicillium citrinum & $100 \%$ \\
\hline Aspergillus flavus ${ }^{\mathrm{b}}$ & $50 \%$ & Aspergillus flavus ${ }^{\mathrm{b}}$ & $50 \%$ \\
\hline Aspergillus niger aggregates & $50 \%$ & Aspergillus niger aggregates & $25 \%$ \\
\hline & & Aspergillus versicolor & $25 \%$ \\
\hline
\end{tabular}

${ }^{a}$ Results expressed in median. ${ }^{b}$ Strains with positive toxigenic profile. ${ }^{c}$ Use of the letters a and $\mathrm{b}$ in the same line indicates significant differences $(p<0.05)$

BSB: Brazilian Sac Brood

The release of mycotoxin-producing species of aflatoxins and ochratoxin A, was verified, and strains of Aspergillus flavus, which produced aflatoxin $\mathrm{B}_{1}$, were isolated. According to Hilldrup and Llewellyn (1979), Apis mellifera is the most sensitive to aflatoxin $\mathrm{B}_{1}$; however, identifying its susceptibility to other mycotoxins requires further research. The presence of aflatoxins in the diet of bees may cause high mortality even at concentrations below $5 \mu \mathrm{g} \mathrm{g}{ }^{-1}$. Aflatoxins act directly on the central nervous system, affect the endocrine system, and compromise the internal defense system of bees, while reducing resistance to mycotic infection (Gliński and Buczek, 2003). Hilldrup et al. (1977) verified the production of aflatoxins in low levels in samples of pollen, honeycomb (nest), larvae, and adult bees, except in unprocessed honey.

Honeybee hives have important defense mechanisms, such as grooming (Traniello et al., 2001) and biochemical barriers (Gliński and Jarosz, 2000), that guarantee the prevention of mycotic infections. In terms of health, strength and organization of the colony are important factors that act to maintain the hive resistant to pathogens. However, this was not assessed in the present study. Evidences show that the pathogens easily settled in populated beehives, and during food-abundant periods, these pathogens released mycotoxins and exhibited colonization in a manner that was subtle and imperceptible to the soldier bees, triggering high mortality rates of the bee larvae (Figure 2). Consequently, high fungal contamination by saprobes can be explained based on the number of isolated species. The invasion was rapid and the contamination was highly intense (Table 2) in a way that hindered all sanitary actions by the bees, such as removal of dead bees, leaving the beehive population with the only resort of absconding. It is possible that the forage bees are the carriers for the pathogen(s) and that pollen foraging and subsequent conversion to bee bread favors mycotic colonization of the beehive, thus, affecting the larvae directly.

The study concludes that bee bread, as a substrate, is an optimal contamination vehicle of beehives, presenting with a microbiota rich in mycotoxin producing fungal species. Pathogenic species were isolated from the beehives, which reduces the immunity of the bees leaving them susceptible to infection by other vectors. This defenseless situation is aggravated in the presence of mycotoxins, which are immunosuppressive compounds, aiding in bee mortality. 


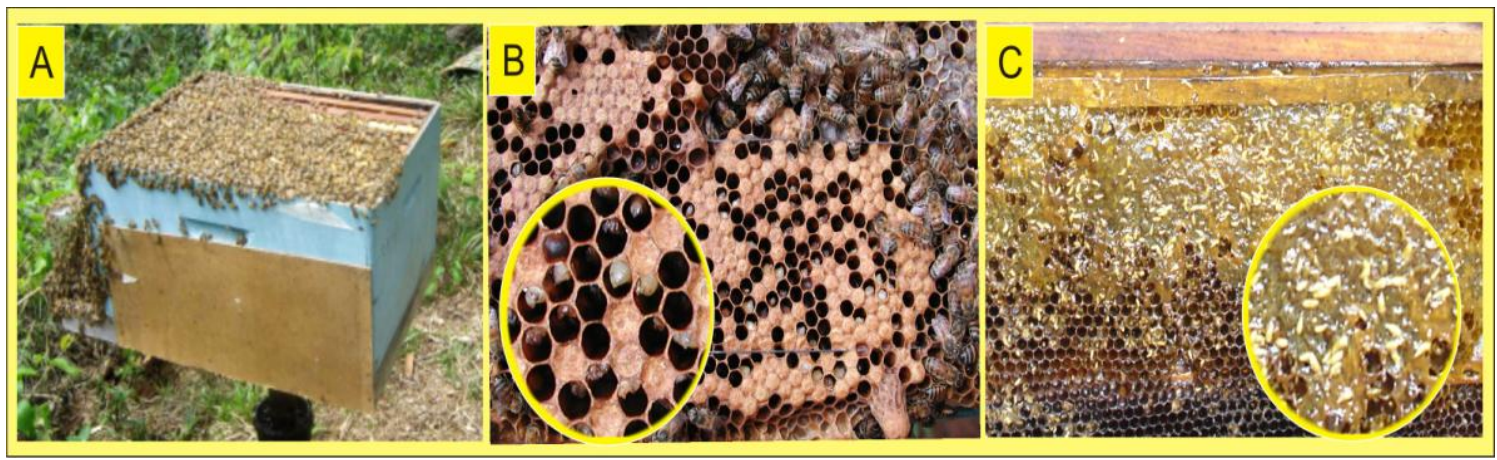

Figure 2. (A) Beehive affected by BSB; (B and C) Immediate symptoms after leaving the dead offspring behind and the invasion of the opportunistic organisms in the honey.

\section{ACKNOWLEDGEMENTS}

The authors would like to thank the Conselho Nacional de Desenvolvimento Científico e Tecnológico $(\mathrm{CNPq})$ and the Pró-Reitoria de Pesquisa da Universidade Federal de Minas Gerais (PRPq-UFMG) for their financial support.

\section{REFERENCES}

BARTH, O.M.; LUZ, C.F.P. Melissopalynological data obtained from a mangrove area near to Rio de Janeiro, Brazil. J. Apicult. Res., v.37, p.155163, 1998.

BRAGULAT, M.R.; ABARCA, M.L.; CABAÑES, F.J. An easy screening method for fungi producing ochratoxin A in pure culture. Int. J. Food Microbiol., v.71, p.139-144, 2001.

CARVALHO, A.C.P.; MESSAGE, D.A. Scientific note on the toxic pollen of Stryphnodendron polyphyllum (Fabaceae, Mimosoidae) which causes sac brood-like symptoms. Apidologie, v.35, p.89-90, 2004.

CASTAGNINO, G.L.B.; MESSAGE, D.; MARCO JÚNIOR, P. Pollen substitute on the reduction of Apis mellifera L. mortality caused by Brazilian Sac Brood. Cienc. Rural, v.41, p.1838-1843, 2011.

CINTRA, P.; MALASPINA, O.; PETACCI, F. et al. Toxicity of Dimorphandra mollis to workers of Apis mellifera. J. Braz. Chem. Soc., v.13, p.115-118, 2002.

DUNN, P.E. Biochemical aspects of insect immunology. Ann. Rev. Entomol., v.31, p.321339, 1986.
FREIBERG, M.; DE JONG, D.; MESSAGE, D. et al. First report of sacbrood virus in honey bee (Apis mellifera) colonies in Brazil. Gen. Mol. Res., v.11, p.3310-3314, 2012.

GEISEN, R. Multiplex polymerase chain reaction for the detection of potential aflatoxin and sterigmatocystin producing fungi. Syst. Appl. Microbiol., v.19, p.388-392, 1996.

GLIŃSKI, Z.; JAROSZ, J. The honeybee defense in mycotic deseases. Honeybee Science, v.21, p.69-70, 2000.

GLIŃSKI, Z:; JAROSZ, J. Infection and immunity in the honey bee Apis mellifera. Apiacta, v.36, p.12-24, 2001.

GLIŃSKI, Z.; BUCZEK, K. Resposta da Apoidea a infecções fúngicas. Apiacta, v.38, p.183-189, 2003.

HANI, B.; DALILA, B.; SALIHA, D. et al. Microbiological sanitary aspects of pollen. $A d v$. Environ. Biol., v.6, p.1415-1420, 2012.

HILLDRUP, J.A.L.; EADIE, T.; LLEWELLYN, G.C. Fungal growth and aflatoxin production on apiarian substrates. J. Assoc. Off. Anal. Chem., v.60, p.96-99, 1977.

HILLDRUP, J.L.; LLEWELLYN, G.C. Acute toxicity of the mycotoxin aflatoxin $\mathrm{B}_{1}$ in Apis mellifera. J. Api. Res., v.18, p.217-221, 1979.

HINKELMANN, K.; KEMPTHORNE, O. Design and Analysis of Experiments $I$ and II. 2.ed. New York: Wiley, 2008. 545p.

JARQUE, C.M.; BERA, A.K. A test for normality of observations and regression residuals. Int. Stat. Rev., v.55, p.163-172, 1987. 
KLICH, M.A. Identification of Common Aspergillus Species. Utrecht, The Netherlands: Centraalbureau voor Schimmelcultures, 2002.

LOUVEAUX, J.; MAURIZIO, A.; VORWOHL, G. Methods of melissopalynology. Bee World, v.51, p.125-138, 1970.

LUZ, C.F.P.; THOMÉ, M.L.; BARTH, O.M. Recursos tróficos de Apis mellifera (Hymenoptera, Apidae) na região de Morro Azul do Tinguá, Estado do Rio de Janeiro. Braz. J. Bot., v.30, p.27-34, 2007.

MESSAGE, D.; BALL, B.V.; SILVA I.C. A serious brood disease affecting Africanized honeybees (Apis mellifera). In: APIMONDIA CONGRESS, 34., 1995, Lausanne. Proceedings... Lausanne: Apimondia, 1995. $203 p$.

MESSAGE, D. Doenças, pragas e predadores das abelhas no Brasil. Rev. Bras. Agropecu., v.15, p.52-59, 2002.

NELSON, P.E.; TOUSSOUN, T.A.; MARASAS, W.F.O. (Eds.). Fusarium species: An Illustrated Manual for Identification. Philadelphia: Pennsylvania State University Press, 1983.

PACHECO, M.R.; BARTH, O.M.; LORENZON, M.C. Tipos polínicos encontrados em colônias de abelhas africanizadas sujeitas à doença cria ensacada brasileira. Cienc. Rural, v.39, p.2141-2145, 2009.
PITT, J.I. A Laboratory guide to commom Penicillium species. 2.ed. Sydney, Australia: CSIRO, Division of Food Processing, 1988. $187 \mathrm{p}$.

PITT, J.I.; HOCKING, A.D. Fungi and Food Spoilage. 3.ed. New York: Springer, 2009. 536p.

ROSA, C.A.R.; RIBEIRO, J.M.M.; FRAGA, M.E. et al. Mycobiota of poultry feeds and ochratoxin-producing ability of isolated Aspergillus and Penicillium species. Vet. Microbiol., v.113, p.89-96, 2006.

SAMSON, R.A.; VAN REENEN-HOEKSTRA, E.S.; FRISVAD, J.C. et al. Introduction to Food and Airborne Fungi. 6.ed. Utrecht, The Netherlands: Centralbureau Voor Schimmelcultures, Institute of the Royal Netherlands Academy of Arts and Sciences, 2000. 388p.

SENAI - Serviço Nacional de Aprendizagem Industrial. Boas Práticas Apícolas no Campo. Brasilia: [s.n.], 2009. 51p.

SOUTWICK, E.E. Hygienic behavior and disease resistance in honey bees. Am. Bee J., v.134, p.751-752, 1994.

TRANIELLO, J.F.A.; ROSENGAUS, R.B.; SAVOIE, K. The development of immunity in a social insect: Evidence for the group facilitation of disease resistance. Proc. Natl. Acad. Sci., v.99, p.6838-6842, 2001. 